\title{
Detection of Cymbidium Mosaic Potexvirus and Odontoglossum Ringspot Tobamovirus Using Immuno-Capillary Zone Electrophoresis
}

\author{
Alvin Jin-Cherng Eun and Sek-Man Wong
}

Department of Biological Sciences, National University of Singapore, Kent Ridge, Singapore 119260.

Accepted for publication 17 March 1999.

\begin{abstract}
Eun, A. J.-C., and Wong, S.-M. 1999. Detection of cymbidium mosaic potexvirus and odontoglossum ringspot tobamovirus using immuno-capillary zone electrophoresis. Phytopathology 89:522-528.

Immuno-capillary zone electrophoresis (I-CZE) is a technique that combines the specificity afforded by serological assays with the sensitivity, rapidity, and automation in detection provided by capillary zone electrophoresis. Cymbidium mosaic potexvirus (CymMV) and odontoglossum ringspot tobamovirus (ORSV) were detected in their purified forms as well as in the crude saps of infected Nicotiana benthamiana leaves and Oncidium orchid flowers. The two orchid virus-antibody complexes were resolved via the combined actions of electrophoretic migration and electro-

osmotic flow along a buffer-filled, uncoated fused-silica capillary. The ICZE fractions collected from both CymMV- and ORSV-antibody complex peaks, as well as the RNA purified from them, retained their infectivity upon inoculation onto Chenopodium quinoa. I-CZE assays were able to detect as little as $10 \mathrm{fg}$ each of both CymMV and ORSV in their purified forms as well as in the crude saps of infected N. benthamiana and Oncidium orchid. As multiple samples can be analyzed rapidly, I-CZE offers an ideal diagnostic technique for routine mass-indexing programs such as virus-free certification, breeding for virus-resistant cultivars, plant quarantine, and germ plasm screening. This is the first report of the application of I-CZE for the detection of plant viruses.
\end{abstract}

The Orchidaceae is the largest and most diverse plant family, consisting of more than 25,000 species in approximately 900 genera. Equally large numbers of orchid hybrids exist, many of which are multigenic (26). From a commercial standpoint, the most important orchids are those grown for cut flowers, which include species and hybrids of Arachnis, Aranda, Asocentrum, Cattleya, Cymbidium, Dendrobium, Laelia, Oncidium, Paphiopedilum, Phalenopsis, Renanthera, and Vanda. Annually, US\$ 35 million worth of orchid cut flowers are produced and exported by Thailand (34). Singapore, being the world's second largest exporter of orchid cut flowers, exports US\$ 24 million worth of cut flowers annually (34). Dendrobium orchid hybrids, one of the most economically important cut and potted floricultural crops grown in Hawaii, commanded a wholesale value of US\$ 6.3 million in 1990 (9).

Orchids are affected by more virus disease problems than most crops (34), reducing their commercial values considerably. Orchid viruses are widespread in cultivated orchids $(2,35)$, with cymbidium mosaic potexvirus (CymMV) and odontoglossum ringspot tobamovirus (ORSV) being the most prevalent $(16,30,32,34)$. Neither virus is known to be transmitted via seed or insect vectors (23). Their high incidence in cultivated orchids has been attributed to the stability and ease of transmission of these two viruses through cultural practices $(16,29)$.

CymMV induces floral and foliar necrosis $(7,33)$. ORSV causes ring spots on leaves and color breaking on flowers (14). Mixed infections of both viruses can cause blossom brown necrotic streak (27). The viruses also reduce plant vigor and lower flower quality, which affect their economic value $(21,22)$. In Singapore, the incidence of CymMV infection alone (54.6\%) in cultivated orchids is

Corresponding author: S.-M. Wong; E-mail address: dbswsm@nus.edu.sg

Publication no. P-1999-0427-02R

(C) 1999 The American Phytopathological Society significantly higher than that of ORSV infection alone (4.0\%). A relatively high percentage of orchids $(14.2 \%)$ are coinfected with both viruses (30).

Capillary zone electrophoresis (CZE) is a relatively new analytical technique first developed by Mikkers and his coworkers in 1979 (20). CZE involves the application of a voltage across a hollow capillary filled with a uniform electrolyte solution. Separations in CZE are achieved as a result of the unequal rates of migration of different components in a sample under the influence of an externally applied electric field via the combined actions of electrophoretic migration and electro-osmotic flow $(1,20)$. Electrophoretic migration is defined as the steady state velocity per unit of field strength, while electro-osmotic flow refers to the bulk flow of liquid due to the effect of the applied electric field on counterions adjacent to the negatively charged capillary wall. The inner walls of the capillary are negatively charged under most $\mathrm{pH}$ conditions $(\mathrm{pH} \geq 2.0)$, resulting in the buildup of positive counterions in the buffer solution adjacent to the capillary wall, termed the electrical double layer. When an electric field is applied, this layer of positive charge is drawn towards the cathode, resulting in the bulk flow of buffer towards it. Protein molecules are separated based on their net charge-to-mass ratios (Fig. 1). CZE is now an important and widely used technique for routine analytical separation of a wide variety of analytes such as amino acids, peptides, proteins, and deoxyribonucleic acids (8).

Immuno-capillary zone electrophoresis (I-CZE) is a technique that combines the specificity afforded by serological assays with the sensitive, rapid, and fully automated detection capability of CZE. Here, we report the application of I-CZE to detect CymMV and ORSV in crude saps of infected Nicotiana benthamiana and Oncidium orchid species. CZE provides a means of detecting the antigen-antibody complexes in real time. This combination of antibody, which confers specificity, and CZE, which provides enhanced sensitivity, speed, and automation, offers a new technique for plant virus detection. 


\section{MATERIALS AND METHODS}

Virus propagation. CymMV-infected $N$. benthamiana leaves $(1 \mathrm{~g})$ were ground in $1 \mathrm{ml}$ of $0.1 \mathrm{M}$ sodium phosphate buffer, $\mathrm{pH}$ 7.5 , and used as inoculum. A sterile cotton bud applicator was used to apply the CymMV inoculum onto healthy leaves of $N$. benthamiana previously dusted with Carborundum powder. The inoculated plants were rinsed with distilled water and left in the dark overnight. The inoculated plants were maintained at $25^{\circ} \mathrm{C}$ with a 12-h photoperiod. The same procedures were applied to propagate ORSV. CymMV- and ORSV-infected leaves were harvested 25 days after inoculation for virus purification.

CymMV purification. CymMV was purified according to Wong and his coworkers (31). Fresh CymMV-infected $N$. benthamiana leaves $(100 \mathrm{~g})$ were homogenized in a Waring blender (Waring Products, New Hartford, CT) for 5 min with $500 \mathrm{ml}$ of extraction buffer $(0.1 \% \beta$-mercaptoethanol, 0.01 M EDTA, and 0.1 M sodium phosphate buffer, $\mathrm{pH}$ 7.5). The extract was clarified with $100 \mathrm{ml}$ of chloroform and centrifuged at $8,000 \times g$ for $10 \mathrm{~min}$ at $4^{\circ} \mathrm{C}$. The supernatant was filtered through cheesecloth before sodium chloride $(\mathrm{NaCl})$ and polyethylene glycol (molecular weight 8,000$)$ were added to concentrations of 0.25 and $4 \%$, respectively. The mixture was centrifuged at $8,000 \times g$ for $20 \mathrm{~min}$ at $4^{\circ} \mathrm{C}$. The pellet was resuspended in $5 \mathrm{ml}$ of resuspension buffer (1\% Triton X-100 and $0.1 \mathrm{M}$ sodium borate buffer, $\mathrm{pH} 8.0$ ) and stirred slowly for $12 \mathrm{~h}$ at $4^{\circ} \mathrm{C}$. The suspension was centrifuged at low speed $(8,000 \times g)$ to remove debris, and the supernatant was subsequently centrifuged at $90,000 \times g$ for $2.5 \mathrm{~h}$ at $4^{\circ} \mathrm{C}$. The pellet was resuspended in $2 \mathrm{ml}$ of $0.01 \mathrm{M}$ sodium borate buffer, $\mathrm{pH} 7.5$, and stored at $-20^{\circ} \mathrm{C}$.

ORSV purification. ORSV was purified according to Chng and her coworkers (4). Fresh ORSV-infected $N$. benthamiana leaves $(100 \mathrm{~g})$ were homogenized for $5 \mathrm{~min}$ with $200 \mathrm{ml}$ of extraction buffer $(0.17 \%$ diethyldithiocarbamic acid and $0.005 \mathrm{M}$ EDTA, pH 7.5). A 1:1 chloroform/butanol mixture was added to clarify the extract. After low-speed centrifugation at $9,000 \times g$ for $10 \mathrm{~min}$ at $4^{\circ} \mathrm{C}$, the supernatant was filtered through cheesecloth and centrifuged at $90,000 \times g$ for $2.5 \mathrm{~h}$ at $4^{\circ} \mathrm{C}$. The pellet was resuspended

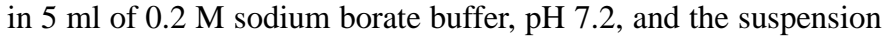
dialyzed in 1 liter of deionized water for $12 \mathrm{~h}$ at $4^{\circ} \mathrm{C}$. The suspension was centrifuged at low speed $(8,000 \times g)$ to remove debris and the purified virus suspension stored at $-20^{\circ} \mathrm{C}$.

Antisera production. Purified CymMV virions (1 mg), suspended in $1 \mathrm{ml}$ of $0.02 \mathrm{M}$ sodium phosphate buffer, $\mathrm{pH} 7.0$, were emulsified with an equal volume of Freund's incomplete adjuvant (Sigma-Aldrich Corp., St. Louis) by vortexing for $1 \mathrm{~min}$. The resulting emulsion was injected intramuscularly into the hind legs of a New Zealand White rabbit. Boost injections of $1 \mathrm{mg}$ each were administered 14, 21, and 28 days after the first injection. Before each boost injection was administered, $10 \mathrm{ml}$ of blood was drawn from the ear of the rabbit. The antiserum collected was aliquoted into fresh $1.5-\mathrm{ml}$ centrifuge tubes for storage at $4{ }^{\circ} \mathrm{C}$. The same protocol was used for the production of ORSV antiserum.

Crude extract preparation. Fresh plant tissue $(0.5 \mathrm{~g})$ was ground in $1 \mathrm{ml}$ of $0.01 \mathrm{M}$ sodium borate buffer, $\mathrm{pH}$ 7.5. The homogenate was centrifuged at low speed $(8,000 \times g)$ to remove plant debris and the supernatant stored at $4{ }^{\circ} \mathrm{C}$ for analysis. Flower samples of CymMV and ORSV mix-infected Oncidium as well as leaf samples of healthy $N$. benthamiana, CymMV-infected $N$. benthamiana, ORSV-infected $N$. benthamiana, CymMV-infected Chenopodium quinoa, and ORSV-infected C. quinoa were prepared.

CZE. CZE analyses were performed on the Beckman P/ACE System 2100 (Beckman Coulter Inc., Fullerton, CA) under normal polarity conditions at which the anode was at the capillary inlet and the cathode at the capillary outlet. Crude saps of plant tissues were added into separate holders and placed in the inlet tray. The fully automated analytical process consisted of capillary rinsing, sample injection, sample separation and detection, and data processing and generation of electropherograms. An uncoated 57-cm fused-silica capillary with an internal diameter of $75 \mu \mathrm{m}$ housed in a temperature-regulated cartridge was used. The temperature within the capillary was maintained at $25^{\circ} \mathrm{C}$ throughout all $\mathrm{CZE}$ runs. The capillary was conditioned before the first run of the day by successive rinsing with $0.1 \mathrm{M}$ hydrochloric acid $(\mathrm{HCl})$ for $5 \mathrm{~min}$, $0.1 \mathrm{M}$ sodium hydroxide $(\mathrm{NaOH})$ for $10 \mathrm{~min}$, and deionized water for $5 \mathrm{~min}$. For each run of the day, prerun rinsing was performed with $50 \mathrm{mM}$ sodium borate buffer, $\mathrm{pH} 9.7$, for $2 \mathrm{~min}$, while postrun rinsing was performed by successive rinsing with $0.1 \mathrm{M} \mathrm{NaOH}$ and deionized water for 2 min each. Samples were injected pneumatically at $3.45 \mathrm{kPa}$ for $5 \mathrm{~s}$. The components within the sample migrated at different rates through the capillary under the influence of high voltages applied across either end. The running buffer used for all CZE runs was $50 \mathrm{mM}$ sodium borate buffer, $\mathrm{pH}$ 9.7. As the separated components passed a glass window situated close to the outlet of the capillary, they were detected by a wavelengthselectable UV detector system comprised of a deuterium lamp, mirrors, wavelength-selectable UV filters, and a photomultiplier tube. The detection absorbance was set at $280 \mathrm{~nm}$ for all CZE runs. This UV detector system was linked to a computer that plotted the signal graphically in the form of an electropherogram (relative absorbance against elution time). After each CZE separation, the major peaks in the electropherograms were identified and their elution times recorded. Fifty successive CZE runs were performed to elute each identified peak. All pooled fractions from each peak were stored at $4^{\circ} \mathrm{C}$ for subsequent analyses via transmission electron microscopy (TEM) to ascertain their identity.

CZE analyses. CZE analyses were performed on CymMV polyclonal antiserum; ORSV polyclonal antiserum; purified CymMV; purified ORSV; healthy, CymMV-infected, or ORSV-infected $N$. benthamiana leaf crude saps; and CymMV and ORSV mix-infected Oncidium orchid flower crude sap.

I-CZE analyses. Serial dilutions (1:10, 1:100, 1:200, 1:400, $1: 600,1: 800$, and 1:1,000 in $50 \mathrm{mM}$ sodium borate buffer, $\mathrm{pH} 9.7$ ) of virus polyclonal antibodies and appropriate amounts of purified viruses were incubated for 10, 20, 30, and $50 \mathrm{~min}$. Similar serial dilutions of healthy, CymMV-infected, or ORSV-infected N. benthamiana leaf crude saps and CymMV and ORSV mix-infected Oncidium flower crude sap were each incubated for the same time

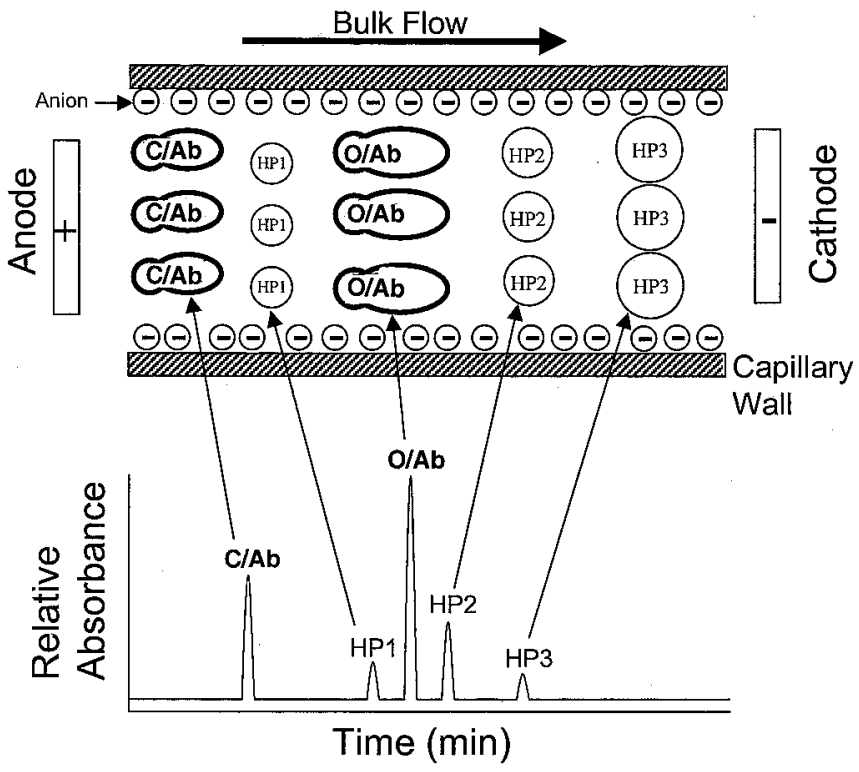

Fig. 1. A schematic diagram showing capillary electrophoresis of protein molecules and their corresponding positions detected in an electropherogram. The interactions among host proteins and virus-antibody complexes influence the bulk flow of the liquid in the capillary. Protein molecules are separated based upon their net charge-to-mass ratios. $\mathrm{C} / \mathrm{Ab}=\mathrm{Cymbidium}$ mosaic potexvirus-antibody complex, $\mathrm{O} / \mathrm{Ab}=$ odontoglossum ringspot tobamovirus-antibody complex, HP1 = host protein $1, \mathrm{HP} 2=$ host protein 2 , and HP3 = host protein 3. 
intervals with either CymMV or ORSV antisera. CZE was performed to determine the optimum dilution of virus-specific antisera and crude saps to produce a distinct virus-antibody complex peak. The crude saps of healthy plants served as negative controls.

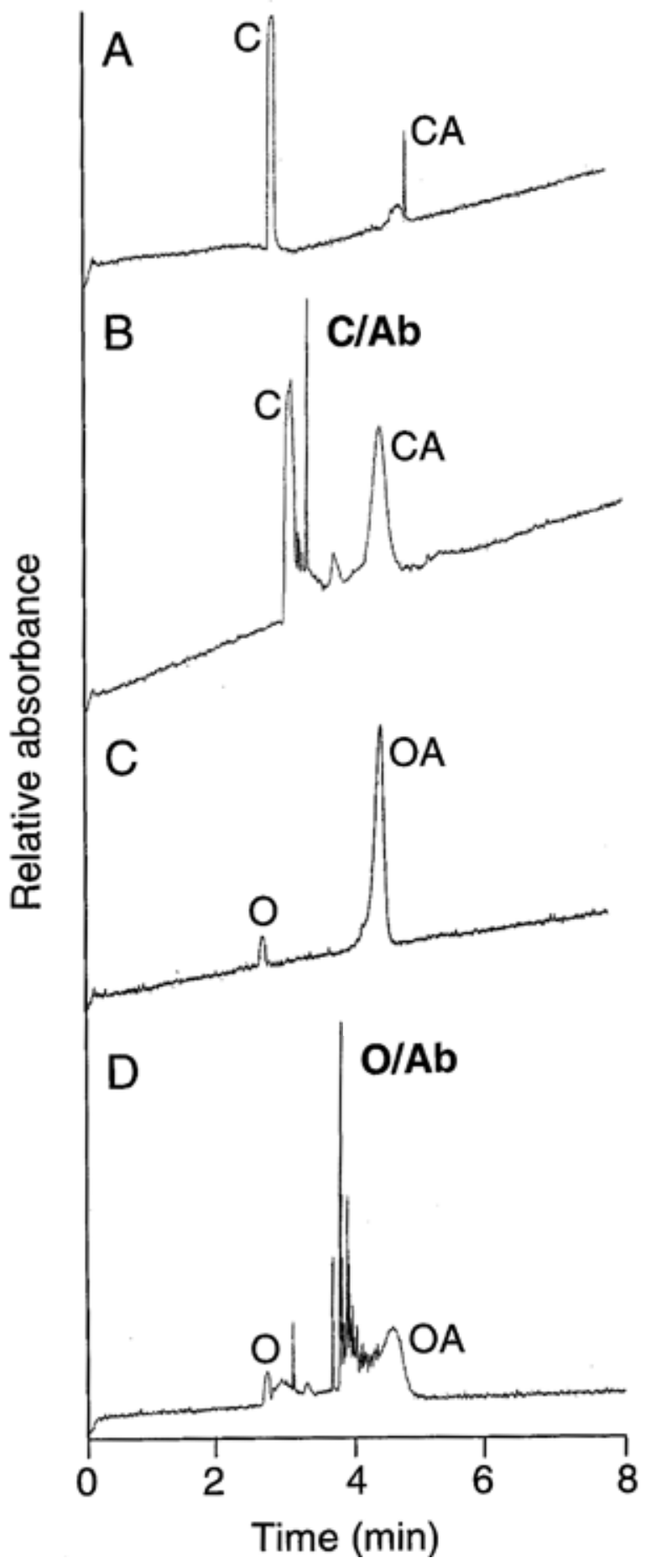

Fig. 2. Capillary zone electrophoresis (CZE) electropherograms of $\mathbf{A}$, purified cymbidium mosaic potexvirus (CymMV) virions; $\mathbf{B}$, purified CymMV virions incubated with CymMV polyclonal antiserum; C, purified odontoglossum ringspot tobamovirus (ORSV) virions; and D, purified ORSV virions incubated with ORSV polyclonal antiserum. Experimental conditions: normal polarity; pneumatic injection $(5 \mathrm{~s}, 3.45 \mathrm{kPa})$; uncoated capillary $(57 \mathrm{~cm} \times$ $75 \mu \mathrm{m}$ internal diameter, $50 \mathrm{~cm}$ to detector); temperature $=25^{\circ} \mathrm{C}$; running buffer $=50 \mathrm{mM}$ sodium borate buffer, $\mathrm{pH} 9.7$; voltage $=20.0 \mathrm{kV}(350 \mathrm{~V}$ $\mathrm{cm}^{-1}$ ); and detection wavelength $=280 \mathrm{~nm}$. Note the detected peaks of the monodispersed CymMV virions (C), the monodispersed ORSV virions (O), the CymMV aggregated virions (CA), the ORSV aggregated virions (OA), the CymMV-antibody complex (C/Ab), and the ORSV-antibody complex $(\mathrm{O} / \mathrm{Ab})$. A to D, Electropherograms were plotted on the same scale.
Purified CymMV and ORSV virions were used as positive controls. The specificity of the CymMV and ORSV polyclonal antisera was tested by incubating CymMV-infected $N$. benthamiana with ORSV polyclonal antisera and ORSV-infected $N$. benthamiana with CymMV polyclonal antisera. Each set of experiments was repeated at least three times.

Viral RNA extraction. The fraction containing the virus-antibody complex was vortexed for $10 \mathrm{~min}$ with $290 \mu \mathrm{l}$ of $0.01 \mathrm{M}$ sodium borate buffer, $\mathrm{pH} 7.5 ; 300 \mu \mathrm{l}$ of VEBA $(20 \%$ Tris, $20 \% \mathrm{NaCl}$, $10 \%$ sodium dodecyl sulfate, and $0.4 \%$ EDTA); and $600 \mu \mathrm{l}$ of watersaturated phenol/chloroform (1:1) mixture. After low-speed centrifugation at $13,000 \times g$ for $10 \mathrm{~min}$ at $4^{\circ} \mathrm{C}$, the aqueous phase was reextracted with phenol/chloroform and subsequently with $300 \mu \mathrm{l}$ of chloroform. The aqueous phase was collected and the RNA precipitated with ethanol. The purified RNA was stored at $-80^{\circ} \mathrm{C}$.

Bioassay. Leaves of $C$. quinoa were sprayed with Carborundum powder. A sterile cotton bud applicator was used to apply the inocula onto the leaves. The leaf surfaces were rinsed with distilled water 5 min after inoculation and the inoculated plants kept in the dark overnight. The plants were maintained in a $20^{\circ} \mathrm{C}$ growth chamber with a $12-\mathrm{h}$ photoperiod. The inocula used were fractions containing CymMV- and ORSV-antibody complexes, viral RNA extracted from the respective virus-antibody complex fractions, purified virions of CymMV or ORSV as a positive control, and sterile deionized water as a negative control for mock inoculation.

TEM. An 8- $\mu$ l aliquot from each of the I-CZE fractions was loaded onto a Formvar- and carbon-coated copper grid. After a 1-min incubation, excess liquid was removed with filter paper and $8 \mu$ of $2 \%$ uranyl acetate was loaded onto the grid. Excess stain was removed with filter paper after a 1-min incubation and the grid was air-dried. All specimens were examined in a Philips CM-10 TEM (Philips Electronics, Amsterdam, the Netherlands). TEM analyses were performed to confirm the identities of the major peaks observed in the electropherograms as well as the presence of CymMV and ORSV virions in C. quinoa.

\section{RESULTS}

Virus propagation and purification. The CymMV- and ORSVinoculated $N$. benthamiana exhibited leaf vein chlorosis and mosaic 25 days after infection. Both viral purification protocols yielded approximately $5 \mathrm{mg}$ of virus per $100 \mathrm{~g}$ of infected leaves. Antisera reactive against CymMV and ORSV were obtained from the immunized rabbits.

CZE analyses. The optimum antiserum dilutions to produce distinct CymMV- and ORSV-antibody complexes were determined to be 1:800. Both CymMV and ORSV polyclonal antisera yielded five distinct peaks that corresponded to $\gamma$-globulin, $\beta$-globulin, $\alpha_{2}$ globulin, $\alpha_{1}$ globulin, and albumin. This result is consistent with that reported in the literature $(3,5,6,12,13,15,17,28)$. The appropriate amounts of purified CymMV and ORSV required to generate discernible peaks were 14 and $38 \mu \mathrm{g}$, respectively. Purified CymMV virion suspension yielded two distinct peaks: peak $\mathrm{C}$ and peak CA (Fig. 2A). Based on the TEM viewing of the corresponding eluted fractions, peak $\mathrm{C}$ was found to contain monodispersed CymMV virions, while peak CA was observed to possess CymMV virion aggregates (data not shown). Similarly, purified ORSV virion suspension yielded two distinct peaks: peak O and peak OA (Fig. 2C), which also contained monodispersed virions and virion aggregates, respectively (data not shown). The injected volume per CZE analysis was $5 \mathrm{nl}$, as determined by the Poiseuille equation (11). Calculated from the injection volume, the CZE detection sensitivity for CymMV and ORSV was determined to be $10 \mathrm{fg}$ each. No distinct peaks were observed in the electropherograms of healthy (Fig. 3A), CymMV-infected (Fig. 3B), or ORSV-infected (Fig. 3E) $N$. benthamiana leaf crude saps. For the flower crude sap of the Oncidium orchid, 12 distinct peaks were observed (Fig. 3H). 
I-CZE analyses of purified viruses. Upon incubation of purified CymMV with its polyclonal antiserum, several peaks were observed between the $\mathrm{C}$ and CA peaks (Fig. 2B). The peak intensities reached maximum after 20 min of incubation, with no further increase in their intensities thereafter. A distinct $\mathrm{C} / \mathrm{Ab}$ peak was fractionated and identified as the CymMV-antibody complex via TEM. Similar results were obtained with ORSV (Fig. 2D), except that peak intensities reached maximum after only $10 \mathrm{~min}$ of in-
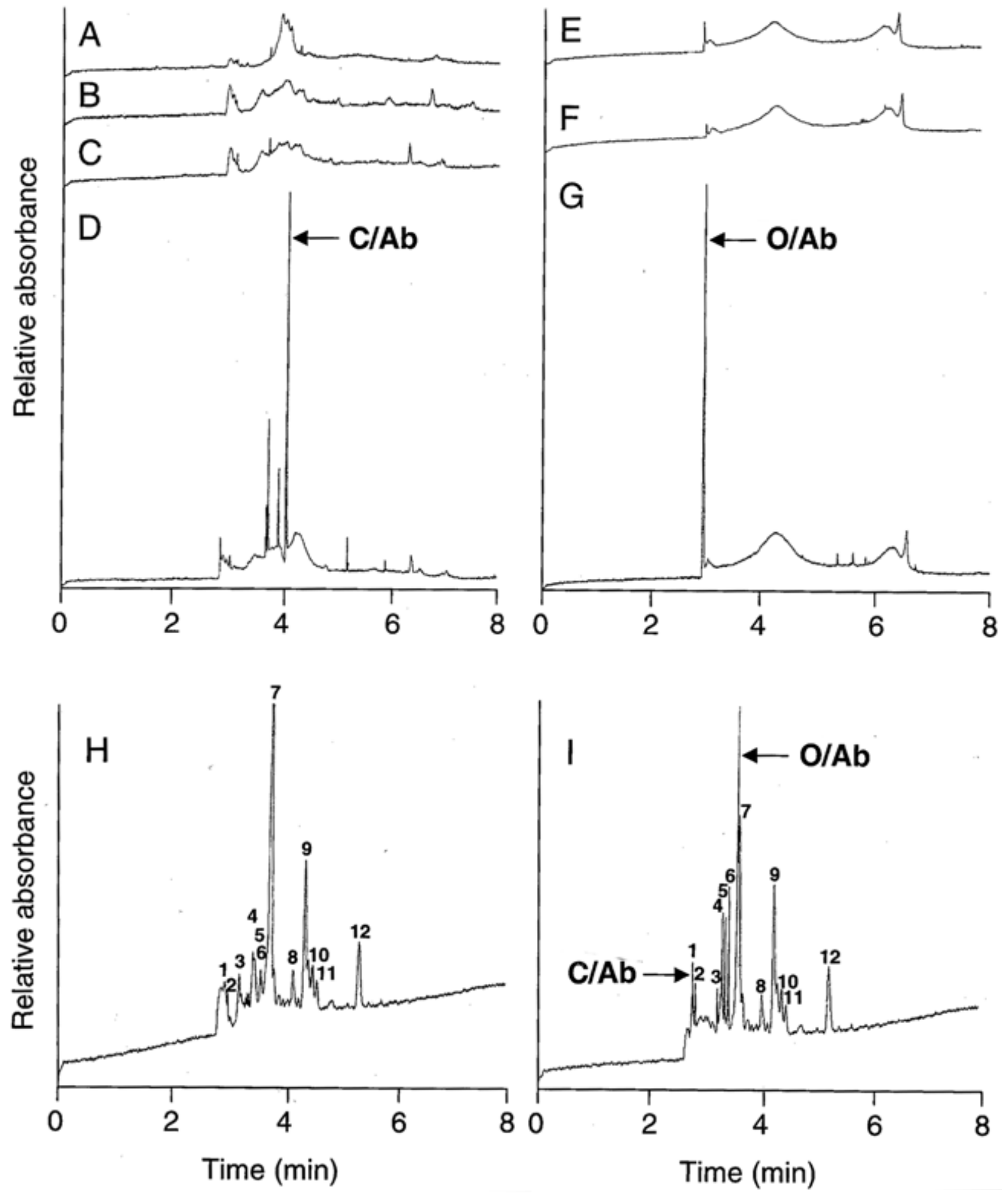

Fig. 3. Capillary zone electrophoresis (CZE) electropherograms of leaf crude saps of A, healthy Nicotiana benthamiana; $\mathbf{B}$, cymbidium mosaic potexvirus (CymMV)infected N. benthamiana; C, CymMV-infected N. benthamiana incubated with odontoglossum ringspot tobamovirus (ORSV) polyclonal antiserum; D, CymMVinfected $N$. benthamiana incubated with CymMV polyclonal antiserum; E, ORSV-infected $N$. benthamiana; F, ORSV-infected N. benthamiana incubated with CymMV polyclonal antiserum; G, ORSV-infected $N$. benthamiana incubated with ORSV polyclonal antiserum; and flower crude saps of $\mathbf{H}$, CymMV and ORSV mix-infected Oncidium orchid; and I, CymMV and ORSV mix-infected Oncidium orchid incubated with CymMV and ORSV polyclonal antisera. Experimental conditions: normal polarity; pneumatic injection $(5 \mathrm{~s}, 3.45 \mathrm{kPa})$; uncoated capillary $(57 \mathrm{~cm} \times 75 \mu \mathrm{m}$ internal diameter, $50 \mathrm{~cm}$ to detector $)$; temperature $=25^{\circ} \mathrm{C}$; running buffer $=50 \mathrm{mM}$ sodium borate buffer, $\mathrm{pH} 9.7$; voltage $=20.0 \mathrm{kV}\left(350 \mathrm{~V} \mathrm{~cm}^{-1}\right)$; and detection wavelength $=280 \mathrm{~nm}$. The number of detected peaks in the mix-infected Oncidium orchid flower corresponded with those incubated with CymMV and ORSV polyclonal antisera. Two virus-antibody complex peaks C/Ab and $\mathrm{O} / \mathrm{Ab}$ were formed. A to $\mathbf{G}$, Electropherograms were plotted on the same scale. $\mathbf{H}$ and $\mathbf{I}$, A larger scale was used to plot electropherograms. 
cubation. The highest peak, $\mathrm{O} / \mathrm{Ab}$, was observed to contain a large amount of ORSV-antibody complex under the TEM. The optimum antiserum dilutions were determined to be 1:800 in $50 \mathrm{mM}$ sodium borate buffer, $\mathrm{pH} 9.7$.

I-CZE analyses of $\boldsymbol{N}$. benthamiana crude saps. The optimum leaf crude sap dilution was determined to be 1:100 in $50 \mathrm{mM}$ sodium borate buffer, $\mathrm{pH}$ 9.7. Upon incubation of CymMV-infected $N$. benthamiana leaf crude sap with the CymMV polyclonal antiserum, a distinct peak, C/Ab, was observed (Fig. 3D). The peak intensities reached maximum after $10 \mathrm{~min}$ of incubation. Such peaks were not observed in leaf crude saps of healthy (Fig. 3A) or CymMV-infected (Fig. 3B) N. benthamiana. Incubation of CymMVinfected $N$. benthamiana leaf crude sap with ORSV polyclonal

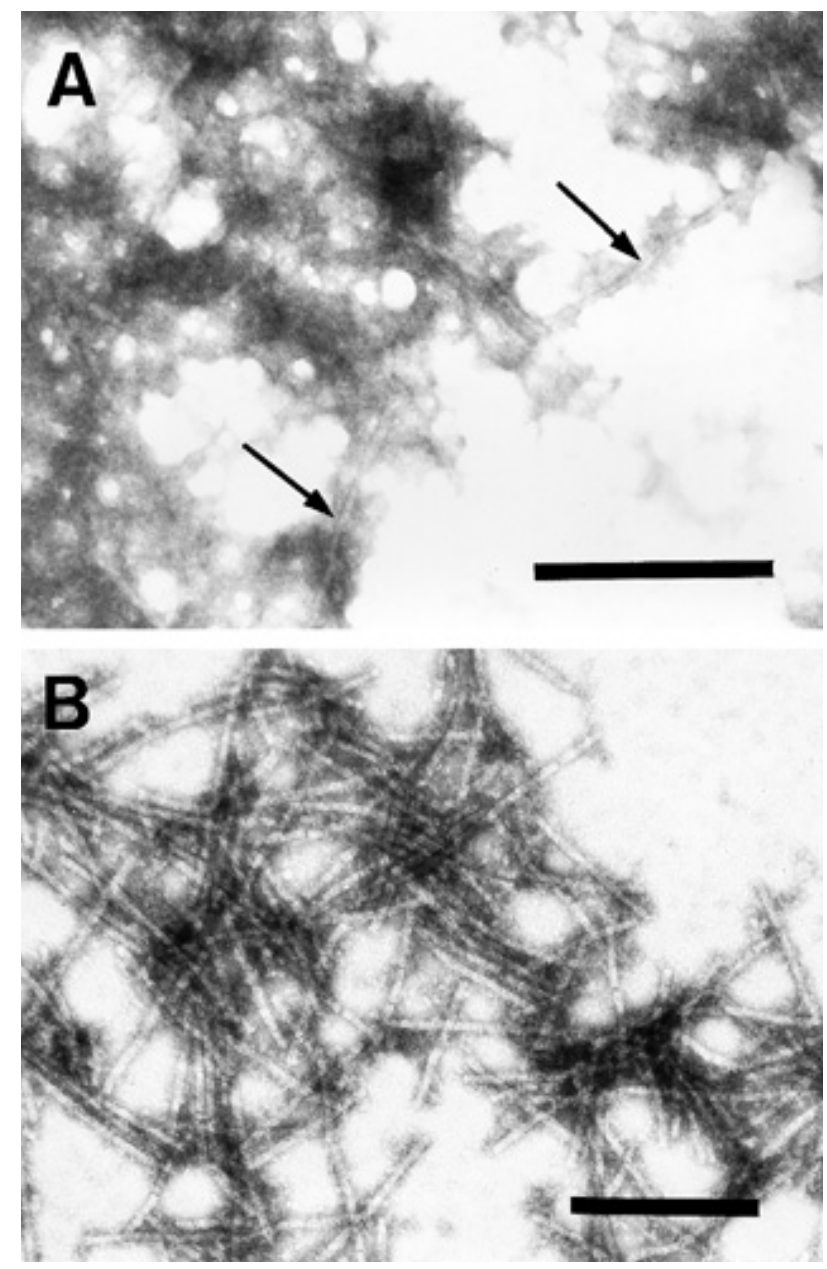

Fig. 4. Transmission electron microscopy of peak fractions corresponding to A, cymbidium mosaic potexvirus (CymMV)-antibody complex C/Ab (arrows) and $\mathbf{B}$, odontoglossum ringspot tobamovirus (ORSV)-antibody complex $\mathrm{O} / \mathrm{Ab}$ after incubation of CymMV and ORSV mix-infected Oncidium orchid with either CymMV or ORSV polyclonal antiserum. Samples were negatively stained with $2 \%$ uranyl acetate. Bar $=0.5 \mu \mathrm{m}$. antiserum yielded a CZE profile similar to that of the leaf crude sap of a CymMV-infected plant alone (Fig. 3C). The highest peak, $\mathrm{C} / \mathrm{Ab}$, was identified as the CymMV-antibody complex via TEM. A similar peak, $\mathrm{O} / \mathrm{Ab}$, was also observed $10 \mathrm{~min}$ after incubation of ORSV-infected $N$. benthamiana leaf crude sap with the ORSV polyclonal antiserum (Fig. 3G). This peak was not observed in healthy (Fig. 3A) and ORSV-infected (Fig. 3E) $N$. benthamiana crude saps. Incubation of ORSV-infected $N$. benthamiana leaf crude sap with CymMV polyclonal antiserum yielded a CZE profile similar to that of the leaf crude sap of ORSV-infected plants (Fig. 3F).

I-CZE analyses of Oncidium crude saps. The CZE peak profiles of CymMV and ORSV mix-infected Oncidium orchid flower crude sap prior to and after incubation with CymMV and ORSV polyclonal antisera corresponded nicely, except for the enhanced $\mathrm{C} / \mathrm{Ab}$ and $\mathrm{O} / \mathrm{Ab}$ peaks, as expected (Fig. $3 \mathrm{H}$ and $\mathrm{I}$ ). TEM analysis of the fractions identified peak 1 as the CymMV-antibody complex $\mathrm{C} / \mathrm{Ab}$ and peak 7 as the ORSV-antibody complex O/Ab (Figs. $3 \mathrm{I}$ and $4 \mathrm{~A}$ and $\mathrm{B}$ ). The $\mathrm{C} / \mathrm{Ab}$ and $\mathrm{O} / \mathrm{Ab}$ peak intensities reached maximum after 50 and $20 \mathrm{~min}$ of incubation, respectively. The incubation time required for maximal virus-antibody peak intensities for the purified virion suspension, the leaf crude sap of CymMVor ORSV-infected $N$. benthamiana, and the flower crude sap of CymMV and ORSV mix-infected Oncidium orchid were summarized in Table 1.

Bioassay. Chlorotic lesions were observed on $C$. quinoa leaves inoculated with CZE-fractionated CymMV and ORSV virions from the mix-infected Oncidium orchid flower crude sap. The RNA purified from the CZE-fractionated CymMV and ORSV virions also caused similar chlorotic lesions. Results were identical to those of the positive controls using purified CymMV or ORSV virions as inoculum. No viral symptoms were observed in the mock-inoculated plants. TEM analysis of the crude saps of CymMV- and ORSV-infected $C$. quinoa leaves confirmed the presence of both viruses.

\section{DISCUSSION}

Current immunoassays employ either an antibody or an antigen immobilized on a solid support. Commonly, the support is a microtiter plate, a glass fiber surface, or an inner surface of a plastic test tube. Detection is accomplished by measuring the activity of an enzyme conjugated to the antibody, as in an enzyme-linked immunosorbent assay, or by using radio-labeled antigen or antibody in a radio-immunoassay (24). Such attachments of one of the reactants to the solid phase is relatively slow. CZE-based immunoassays analyze antigen-antibody reaction in free solution in real time without the need for antigen or antibody immobilization. It requires only up to $50 \mathrm{~min}$ of incubation time for both CymMV and ORSV in mix-infected Oncidium orchid to reach equilibrium in binding to their antibodies and to be detected (Table 1). It offers increased speed and precision, thus eliminating the need to find conditions and materials for stable and reproducible immobilization of antibodies or antigens. CZE has three additional advantages: (i) it requires only a small amount of test material; (ii) it is highly

TABLE 1. Effect of incubation time of antibody to antigen on detection sensitivity of purified cymbidium mosaic potexvirus (CymMV) and odontoglossum ringspot tobamovirus (ORSV) virions, leaf crude saps of CymMV- and ORSV-infected Nicotiana benthamiana, and flower crude sap of Oncidium species via immuno-capillary zone electrophoresis (I-CZE)

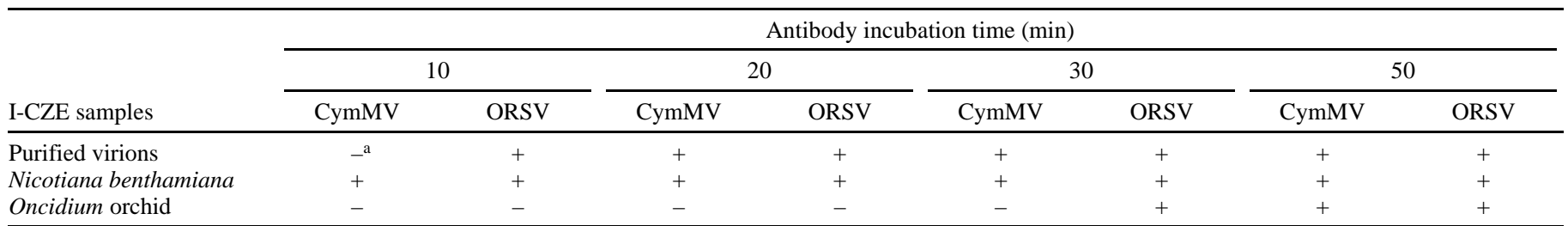

a + = Detected; and $-=$ not detected. 
reproducible, as an antibody-virus peak is present in the same place for the same virus-infected plant sample; and (iii) its heat dissipation is enhanced due to the utilization of a capillary. This affords an extremely large surface area-to-volume ratio, permitting the use of high voltage potentials to separate charged molecules. The use of high-potential fields leads to extremely efficient separation of molecules within minutes.

CZE is a highly resolving electrophoretic method, enabling distinct separation of the components in a sample based on their molecular mass as well as their charge-to-mass ratio. Thus, the viral aggregates (peaks CA and OA), due to their larger mass, migrated at slower rates in comparison to the monodispersed viruses (peaks $\mathrm{C}$ and $\mathrm{O}$ ) (Fig. 2A and C). Based on this fact, it can be postulated that ORSV virions are more likely to form aggregates in a suspension than are CymMV virions. Virion morphology could have played a role in virus aggregation. The straight and rigid ORSV virions probably aggregate more readily than do the flexuous CymMV virions. The time required for CZE detection of CymMV and ORSV in mix-infected Oncidium orchid is less than 4 min (Fig. 3I). Due to its high resolving power, this CZE technique may be applied to the detection of plant viruses with low titers in infected tissues. Plant virus titers in infected plants can also be quantified using CZE, as the quantity of each separated component can be estimated by the area under its associated peak (15).

It is interesting that the virus-antibody complex is resolved into a single peak. We hypothesize that this distinct peak contains monodispersed virions bound with equal valency of antibody molecules, thus forming individual stable virus-antibody complexes. Each $\mathrm{C} / \mathrm{Ab}$ (Fig. 2B) and O/Ab (Fig. 2D) peak represents a pool of such stable complexes that travels at the same rate in the capillary due to its overall mass and net charge. The migration of such stable complexes are interfered by the presence of different host proteins. As a result, the CymMV- and ORSV-antibody complexes resolved at different time intervals from purified virion suspension (Fig. 2B and D), virus-infected $N$. benthamiana (Fig. 3D and G), and Oncidium orchid (Fig. 3I). Both CymMV and ORSV virions could maintain particle integrity (Fig. 4A and B) and infectivity after subjected to $20 \mathrm{kV}$ of CZE. This suggests that both viruses are highly stable.

The CZE profiles of healthy (Fig. 3A), CymMV-infected (Fig. 3B), and ORSV-infected (Fig. 3E) N. benthamiana leaf crude saps differ from each other. It is known that host- and pathogen-related proteins are altered in diseased plants (19). The physiological and biochemical changes in virus-infected plants may involve a decrease in the photosynthetic enzyme ribulose-bisphosphate carboxylase oxygenase and an increase in certain enzymes such as the polyphenoloxidases. These proteins and other plant proteins vary among different host plants and give rise to different protein profiles observed in the electropherograms. The overall interactions among these proteins and the virus-antibody complexes influence the bulk flow of the liquid in the capillary (Fig. 1), thus affecting the sequence of peaks detected. This explains why the detection of the $\mathrm{O} / \mathrm{Ab}$ complex peak precedes the C/Ab complex peak in leaf crude sap of virus-infected $N$. benthamiana (Fig. 3D and G); whereas the reverse sequence of peak appearance occurs in flower crude sap of mixed-infected Oncidium orchid (Fig. 3I).

I-CZE offers an ideal diagnostic technique for routine mass-indexing programs such as virus-free certification, breeding, plant quarantine, and germ plasm screening. Crude saps of plant tissues are incubated with virus-specific antibodies in sample vials and automatically injected into the capillary after a minimal incubation period of 10 to $50 \mathrm{~min}$. Up to 30 test samples can be analyzed automatically. Results can be recorded in a computer for further analysis. It provides an alternative to the recent application of polymerase chain reaction $(18,25)$ or digoxigenin-labeled cRNA probes (10) to detect CymMV and ORSV in orchids. In summary, I-CZE is a specific, sensitive, and rapid diagnostic technique for plant virus detection.

\section{ACKNOWLEDGMENTS}

This work was supported by research grant RP972398 from the National University of Singapore (NUS), Republic of Singapore. We thank $\mathrm{L}$. $\mathrm{Ng}$ for her help in the preparation of the electropherograms.

\section{LITERATURE CITED}

1. Adamson, N. J., and Reynolds, E. C. 1997. Rules relating electrophoretic mobility, charge and molecular size of peptides and proteins. J. Chromatogr. B Biomed. Appl. 699:133-147.

2. Chang, M. U. 1985. Studies on the infection of virus in orchids. J. Natl. Sci. 5:211-220.

3. Chen, F. T. A., and Sternberg, J. C. 1994. Characterisation of proteins by capillary electrophoresis in fused-silica columns: Review on serum protein analysis and application to immunoassays. Electrophoresis 15:13-21.

4. Chng, C. K., Wong, S. M., Mahtani, P. H., Loh, C. S., Goh, C. J., Kao, C. C., Chung, M. C. M., and Wanatabe, Y. 1996. The complete sequence of a Singapore isolate of odontoglossum ringspot virus and comparison with other tobamoviruses. Gene 171:155-161.

5. Clark, R., Katzmann, J. A., Wiegert, E., Namyst-Goldberg, C., Sanders, L., Oda, R. P., Kyle, R. A., and Landers, J. P. 1996. Rapid capillary electrophoretic analysis of human serum proteins: Qualitative comparison with high-throughput agarose gel electrophoresis. J. Chromatogr. A 744: 205-213.

6. Dolnik, V. 1995. Capillary zone electrophoresis of serum proteins: Study of separation variables. J. Chromatogr. A 709:99-110.

7. Dunn, E. 1980. Virus diseases of Dendrobium. Third annual ornamental short course. Hawaii Inst. Trop. Agric. Hum. Resour. Res. Ext. Ser. 007: 77-81.

8. Ewing, A. G., Wallingford, R. A., and Olefirowicz, T. M. 1989. Capillary electrophoresis. Anal. Chem. 61:292-303.

9. Hu, J. S., Ferreira, S., Wang, M., and Xu, M. Q. 1993. Detection of cymbidium mosaic virus, odontoglossum ringspot virus, tomato spotted wilt virus, and potyviruses infecting orchids in Hawaii. Plant Dis. 77:464-468.

10. Hu, W. W., and Wong, S. M. 1998. The use of DIG-labelled cRNA probes for the detection of cymbidium mosaic potexvirus (CymMV) and odontoglossum ringspot tobamovirus (ORSV) in orchids. J. Virol. Methods 70:193-199.

11. Huang, X., Gordon, M. J., and Zare, R. N. 1988. Current monitoring method for measuring the electro-osmotic flow rate in capillary zone electrophoresis. Anal. Chem. 60:1837-1838.

12. Jenkins, M. A., and Guerin, M. D. 1996. Capillary electrophoresis as a clinical tool. J. Chromatogr. B Biomed. Appl. 682:23-34.

13. Jenkins, M. A., and Guerin, M. D. 1997. Capillary electrophoresis procedures for serum protein analysis: Comparison with established techniques. J. Chromatogr. B Biomed. Appl. 699:257-268.

14. Jensen, D. D., and Gold, A. H. 1951. A virus ring spot of odontoglossum orchid: Symptoms, transmission, and electron microscopy. Phytopathology 41:648-653.

15. Kim, J. W., Park, J. H., Park, J. W., Doh, H. J., Heo, G. S., and Lee, K. J. 1993. Quantitative analysis of serum proteins separated by capillary electrophoresis. Clin. Chem. 39:689-692.

16. Lawson, R. H., and Brannigan, M. 1986. Virus diseases of orchids. Pages 249 in: Handbook on Orchid Pests and Diseases. American Orchid Society, West Palm Beach, FL.

17. Lehmann, R., Liebich, H., Grubler, G., and Voelter, W. 1995. Capillary electrophoresis of human serum proteins and apoliproteins. Electrophoresis 16:998-1001.

18. Lim, S. T., Wong, S. M., Yeong, C. Y., Lee, S. C., and Goh, C. J. 1993. Rapid detection of cymbidium mosaic virus by the polymerase chain reaction (PCR). J. Virol. Methods 41:37-46.

19. Matthews, R. E. F. 1992. Fundamentals of Plant Virology. Academic Press Inc., New York.

20. Mikkers, F. E. P., Everaerts, F. M., and Verheggen, T. P. E. M. 1979. High-performance zone electrophoresis. J. Chromatogr. 169:11-20.

21. Okemura, A. K., Kamemoto, H., and Ishii, M. 1984. Incidence and expression of cymbidium mosaic virus in Dendrobium hybrids. Hawaii Inst. Trop. Agric. Hum. Resour. Res. Ext. Ser. 033:3-13.

22. Pearson, M. N., and Cole, J. S. 1991. Further observations on the effects of cymbidium mosaic virus and odontoglossum ringspot virus on the growth of Cymbidium orchids. J. Phytopathol. 131:193-198.

23. Porter, K. G., Kuehnle, A. R., and Hu, J. S. 1996. Lack of seed transmission of cymbidium mosaic virus in Dendrobium. Lindleyana 11:211-213.

24. Pritchett, T., Evangelista, R. A., and Chen, F. T. A. 1995. Capillary electrophoresis-based immunoassays: Speedy alternative to solid-phase immunoassays. Biotechnology 13:1449-1450.

25. Seoh, M. L., Wong, S. M., and Zhang, L. 1998. Simultaneous TD/RTPCR detection of cymbidium mosaic potexvirus and odontoglossum 
ringspot tobamovirus with a single pair of primers. J. Virol. Methods 72: 197-204.

26. Sheehan, T. J. 1980. Orchids. Pages 113-142 in: Introduction to Floriculture. R. A. Larson, ed. Academic Press, New York.

27. Thornberry, H. H., and Phillippe, M. R. 1964. Orchid disease: Cattleya blossom brown necrotic streak. Plant Dis. Rep. 48:936-940.

28. Wehr, T., Rodriguez-Diaz, R., and Liu, C. M. 1997. Capillary electrophoresis of proteins. Adv. Chromatogr. 37:237-361

29. Wisler, G. C. 1989. How to Control Orchid Viruses: The Complete Guidebook. Maupin House Publishing, Gainesville, FL.

30. Wong, S. M., Chng, C. G., Lee, Y. H., Tan, K., and Zettler, F. W. 1994. Incidence of cymbidium mosaic and odontoglossum ringspot viruses and their significance in orchid cultivation in Singapore. Crop Prot. 13:235-239.

31. Wong, S. M., Mahtani, P. H., Lee, K. C., Yu, H. H., Tan, Y., Neo, K. K.,
Chan, Y., Wu, M., and Chng, C. G. 1997 Cymbidium mosaic potexvirus RNA: Complete nucleotide sequence and phylogenetic analysis. Arch. Virol. 142:383-391.

32. Wong, S. M., Soo, F., and Lim, G. 1990. Determination of cymbidium mosaic virus distribution in apical, middle and basal regions of Cattleya bowell leaves. Int. J. Trop. Plant Dis. 8:199-204.

33. Yuen, C., Kamemoto, H., and Ishii, M. 1979. Transmission of cymbidium mosaic virus through seed propagation in Dendrobium. Am. Orchid Soc. Bull. 48:1245-1247.

34. Zettler, F. W., Ko, N.-J., Wisler, G. C., Elliott, M. S., and Wong, S.-M. 1990. Viruses of orchids and their control. Plant Dis. 74:621-626.

35. Zettler, F. W., Wisler, G. C., Elliott, M. S., and Ko, N.-J. 1987. Some new, potentially significant viruses of orchids and their probable means of transmission. Am. Orchid Soc. Bull. 56:1044-1051. 